\title{
Hematopoietic stem cells proliferate until after birth and show a reversible phase-specific engraftment defect
}

\author{
Michelle B. Bowie, ${ }^{1}$ Kristen D. McKnight, ${ }^{1}$ David G. Kent, ${ }^{1}$ Lindsay McCaffrey, ${ }^{1}$ \\ Pamela A. Hoodless, ${ }^{1,2}$ and Connie J. Eaves ${ }^{1,2}$ \\ ${ }^{1}$ Terry Fox Laboratory, BC Cancer Agency, Vancouver, British Columbia, Canada. \\ 2Department of Medical Genetics, University of British Columbia, Vancouver, British Columbia, Canada.
}

\begin{abstract}
The regulation of HSC proliferation and engraftment of the BM is an important but poorly understood process, particularly during ontogeny. Here we show that in mice, all HSCs are cycling until 3 weeks after birth. Then, within 1 week, most became quiescent. Prior to 4 weeks of age, the proliferating HSCs with long-term multilineage repopulating activity displayed an engraftment defect when transiting $S / G_{2} / M$. During these cell cycle phases, their expression of CXC chemokine ligand 12 (CXCL12; also referred to as stromal cell-derived factor 1 [SDF-1]) transiently increased. The defective engrafting activity of $H S C s$ in $S / G_{2} / M$ was reversed when cells were allowed to progress into $G_{1}$ prior to injection or when the hosts (but not the cells) were pretreated with a CXCL12 antagonist. Interestingly, the enhancing effect of CXCL12 antagonist pretreatment was exclusive to transplants of long-term multilineage repopulating HSCs in $\mathbf{S} / \mathrm{G}_{2} / \mathbf{M}$. These results demonstrate what we believe to be a new HSC regulatory checkpoint during development. They also suggest an ability of HSCs to express CXCL12 in a fashion that changes with cell cycle progression and is associated with a defective engraftment that can be overcome by in vivo administration of a CXCL12 antagonist.
\end{abstract}

\section{Introduction}

HSCs are defined as cells with multilineage hematopoietic differentiation potential and sustained self-renewal activity. Operationally, HSCs are detected by their ability to regenerate long-term multilineage hematopoiesis in myeloablated recipients. HSC numbers can be quantified by endpoints that measure this regenerative activity in genetically distinguishable, radioprotected hosts transplanted with limiting numbers of HSCs (1). HSCs are also characterized by extensive heterogeneity. Variability in many HSC properties is dictated by changes in their state of activation, and the consequent changes in these properties are thus reversible. For example, most of the HSCs present in normal adult mice are in a deeply quiescent $\left(\mathrm{G}_{0}\right)$ state $(2-4)$ and, in association with this status, they express CD38 but not CD34 or Mac1 $(5,6)$. These $\mathrm{G}_{0}$ HSCs also actively exclude certain fluorescent dyes, such as rhodamine-123 (Rho) $(7,8)$ and Hoechst 33342 (Hst) (9). The latter property underlies the detection of adult mouse HSCs as side population (SP) cells (10). However, when HSCs are activated, they rapidly downregulate expression of $\mathrm{CD} 38(6,11)$, increase expression of CD34 (12) and Mac1 $(13,14)$, and acquire a Rho bright, nonSP phenotype (15). In association with these changes, some HSCs begin to differentiate and hence permanently lose their long-term repopulating activity, but many do not in spite of their transiently altered phenotype (16). Another property of HSCs that appears to vary reversibly is their ability to exit from the circulation into the

Nonstandard abbreviations used: $\alpha 4$ int, $\alpha 4$-integrin; CRU, competitive repopulating unit; CXCL12, CXC chemokine ligand 12; FACS, fluorescence-activated cell sorting; FL, fetal liver; 5-FU, 5-fluorouracil; HA, hyaluronic acid; HF/2, Hank's balanced salt solution containing $2 \%$ FCS; Hst, Hoechst $33342 ;{ }^{3} \mathrm{H}-\mathrm{Tdr},{ }^{3} \mathrm{H}$-thymidine; lin, lineage marker; OPN, osteopontin; PI, propidium iodide; Py, pyronin Y; Rho, rhodamine123 ; SF, Steel factor; SP, side population.

Conflict of interest: The authors have declared that no conflict of interest exists. Citation for this article: J. Clin. Invest. 116:2808-2816 (2006). doi:10.1172/JCI28310.
$\mathrm{BM}$ and reinitiate hematopoiesis. Quiescent adult mouse HSCs can execute this process at near unit efficiency in suitably myelosuppressed hosts, as shown by their detection at purities of $20 \%$ and higher following intravenous injection $(15,17,18)$. However, notable changes in HSC engrafting potential have also been found to accompany the progression of HSCs through the cell cycle both in vitro and in vivo (3,19-21). Specifically, HSC activity was not detectable in suspensions of adult or neonatal hematopoietic cells in the $\mathrm{S} / \mathrm{G}_{2} / \mathrm{M}$ phases, even when substantial HSC activity was found in the corresponding $G_{1}$ cells. The transient nature of the silencing of HSC homing activity during the progression of these cells through $S / G_{2} / M$ is inferred from the fact that the populations studied did not contain $\mathrm{G}_{0}$ HSCs or were expanding their HSC content, although the reacquisition of repopulating activity by incapacitated $S / G_{2} / M$ HSCs was not formally documented. The molecular mechanisms that control the BM-homing activity of HSCs are not fully elucidated, although a number of cell-surface ligand-receptor interactions with known involvement in cell adhesion and chemotaxis have been implicated. These include CXC chemokine ligand 12 (CXCL12; also referred to as stromal cell-derived factor 1 [SDF-1]) and CXC chemokine receptor 4 (CXCR4), Steel factor (SF) and c-kit, CD44 and hyaluronic acid or osteopontin, VLA4 and VCAM1, and P2Y-like receptor and an unknown ligand (22-25). The expression and activity of some of these appear to be variably affected by cytokine exposure $(26,27)$; however, their specific involvement in the engraftment defect of HSCs in $S / G_{2} / M$ has remained unclear.

In the mouse embryo, pluripotent hematopoietic cells with longterm repopulating ability first appear in the aorta-gonad-mesonephros region on the ninth day of gestation (28). These cells then migrate to the fetal liver (FL) and later to the $\mathrm{BM}$, their numbers continually expanding until young adulthood is reached (29). Most of the HSCs in the 14.5-dpc FL have phenotypic characteris- 
A

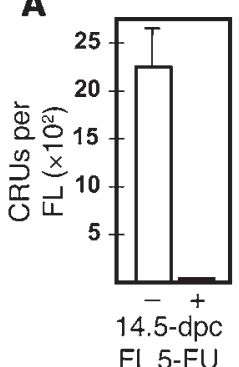

B

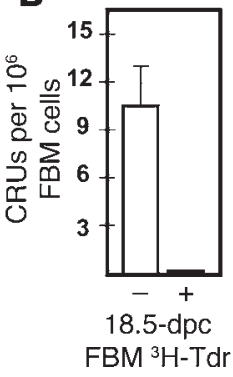

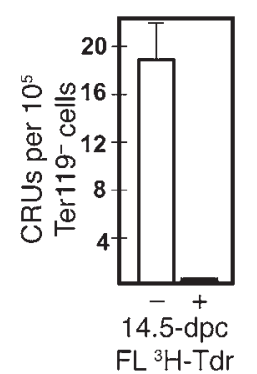
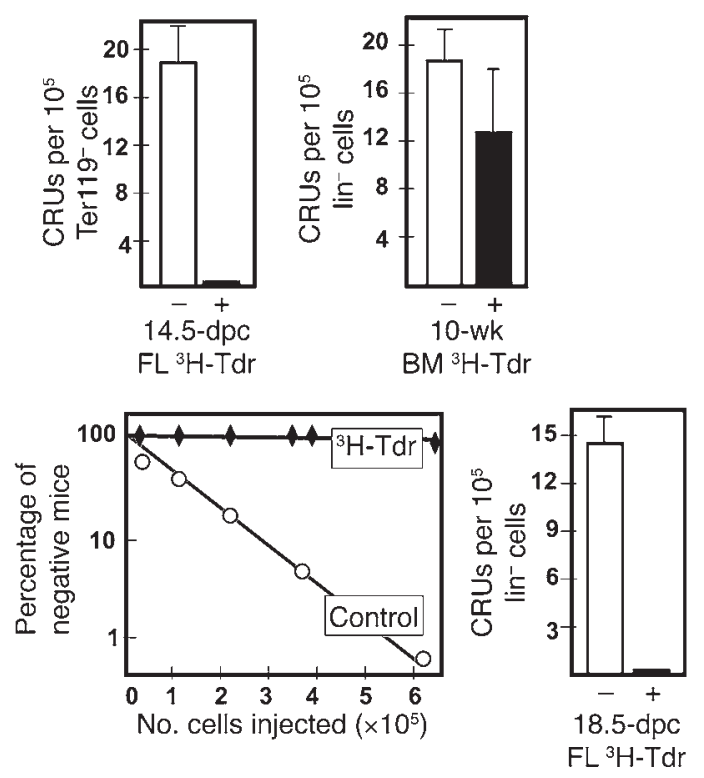

\section{Figure 1}

All fetal HSCs are sensitive to cell cycle-specific drugs. Cells from different mouse embryonic tissues were analyzed for CRU content either 16 hours after injection of the pregnant mother with $100 \mathrm{mg} / \mathrm{kg} \mathrm{5-FU} \mathrm{(+)} \mathrm{or} \mathrm{PBS} \mathrm{(-)} \mathrm{or} \mathrm{after} \mathrm{in} \mathrm{vitro} \mathrm{incubation} \mathrm{of} \mathrm{the}$ cells for 16 hours with $(+)$ or without $(-)$ high-specific activity ${ }^{3} \mathrm{H}-\mathrm{Tdr}$. (A) Shown are the effects of 5-FU injection on 14.5-dpc FL CRUs (left panel; data pooled from 3 independent experiments) as well as the effects of ${ }^{3} \mathrm{H}-\mathrm{Tdr}$ on 14.5-dpc FL CRUs (middle panel) and the lack of effect of ${ }^{3} \mathrm{H}-\mathrm{Tdr}$ on $\mathrm{CRU}$ f from adult (10-week-old) mice assessed in parallel (right panel; data pooled from 6 independent experiments). (B) The effects of ${ }^{3} \mathrm{H}$-Tdr on 18.5-dpc fetal BM (FBM) and FL CRUs (left and right panels; data pooled from 4 independent experiments). The middle panel shows the complete data set from the limiting dilution analysis of the 18.5-dpc fetal BM cells. ${ }^{\star} P<0.001$. tics of activated adult HSCs (CD38- $\mathrm{Mac1}^{+}, \mathrm{CD} 34^{+}, \mathrm{Rho}^{+}$, non-SP) $(13,14)$, as might be expected for an expanding HSC population. The proportion of HSCs in the 14.5-dpc FL that are proliferating has been previously estimated from phenotyping studies to be approximately $35 \%$ (3), although a more direct measurement of this fraction has not been reported.

As a first step toward elucidating the mechanisms that regulate changes in HSC turnover and engraftment properties during ontogeny, we designed experiments to assess their proliferative status in mice at different stages of development. Our results showed that the entire HSC population remained in cycle until the third week after birth regardless of the tissue in which the HSCs were located. Then within 1 week, the majority of the HSCs switched abruptly from an actively dividing to a quiescent state. Until this switch occurred, those HSCs that were in $\mathrm{S} / \mathrm{G}_{2} / \mathrm{M}$ showed the same engrafting defect previously demonstrated for adult HSCs that have been stimulated to divide. Interestingly, prior to the establishment of a quiescent HSC population, the HSCs in $S / G_{2} / M$ were found to express higher levels of CXCL12 than those in $\mathrm{G}_{1}$, and their defective engrafting activity could be completely reversed, either by holding them ex vivo for a few hours until they reentered $\mathrm{G}_{1}$ or by pretreating the host with a specific antagonist of CXCL12.

\section{Results}

All HSCs in the 14.5-dpc FL are rapidly proliferating. To measure the proportion of HSCs that are in cycle in the 14.5-dpc FL, we used 3 complementary strategies. In the first, we injected pregnant mice at $13.5 \mathrm{dpc}$ with $100 \mathrm{mg} / \mathrm{kg}$ of 5 -fluorouracil (5-FU) and then removed the fetuses 16 hours later, prepared cell suspensions from the FLs, and measured the number of HSCs present using a limiting dilution transplantation assay for long-term (16-week) competitive repopulating units (CRUs) (1). In these experiments, we detected very few CRUs in the FLs of the 5-FU-treated embryos (Figure 1A). A comparison of the CRU yield from the 5-FU-treated FLs with the control FLs from pregnant mice injected $13.5 \mathrm{dpc}$ with PBS indicated that the 5-FU treatment had reduced the expected CRU population in vivo by more than 1,000-fold.
We then assessed the cycling status of HSCs in the 14.5-dpc FL by measuring the proportion of CRUs that survived a 16-hour exposure to high-specific activity ${ }^{3} \mathrm{H}$-thymidine $\left({ }^{3} \mathrm{H}-\mathrm{Tdr}\right)(30)$. Sixteen hours was anticipated to be sufficient to allow all cycling HSCs to enter S-phase, which we later confirmed (see below), with minimal exit of any quiescent cells from $\mathrm{G}_{0}(31)$, as demonstrated for adult BM HSCs, most of which were in $\mathrm{G}_{0}$ (Figure 1A). For these experiments, the Ter $119^{+}$(erythroid) cells were first removed from the FL cells to give a 10-fold enrichment in HSC content, and cells were then incubated in a serum-free medium supplemented with $50 \mathrm{ng} / \mathrm{ml} \mathrm{SF}$ only. This growth factor condition was chosen based on other data demonstrating that freshly isolated 14.5-dpc FL CRUs are maintained at the same numbers for 16 hours under these conditions (M.B. Bowie and C.J. Eaves, unpublished observations). The results of the ${ }^{3} \mathrm{H}-\mathrm{Td}$ r suicide experiments showed that this treatment reduced the number of CRUs in the suspensions of 14.5-dpc FL cells more than 100 -fold $(P<0.001$; Figure $1 \mathrm{~A})$, whereas the same treatment had no significant effect on the recovery of CRUs in similarly treated lineage marker-negative (lin-) BM cells from young adult (10-weekold) mice compared with either control cells incubated without ${ }^{3} \mathrm{H}$ $\operatorname{Tdr}(P=0.17)$ or starting values (data not shown).

We then assessed the distribution of CRUs between the $G_{0}$ and $\mathrm{G}_{1} / \mathrm{S} / \mathrm{G}_{2} / \mathrm{M}$ fractions of Ter119- 14.5 -dpc FL cells. These subsets were isolated by fluorescence-activated cell sorting (FACS) on the basis of their staining with Hst and Pyronin Y (Py) (32). A representative FACS profile of the Hst- and Py-stained cells is shown in Figure 2A. The combined results of in vivo assays of 14.5-dpc sorted cells from 4 independent experiments are shown in Figure 3 and indicate that all transplantable CRU activity was confined to the $\mathrm{G}_{1} / \mathrm{S} / \mathrm{G}_{2} / \mathrm{M}$ fraction. Based on the total number of $\mathrm{G}_{0}$ cells assayed, the proportion of quiescent HSCs was estimated to be less than $0.02 \%$.

HSCs undergo a complete and abrupt change in cycling activity between 3 and 4 weeks after birth. Since HSCs are known to be present in the $\mathrm{BM}$ of fetal mice at later times of gestation, it was of interest to investigate whether HSCs first become quiescent in the fetus at that site. To address this question, we used the 16 -hour ${ }^{3} \mathrm{H}$-Tdr suicide assay to determine the cycling status of the CRUs present 
A

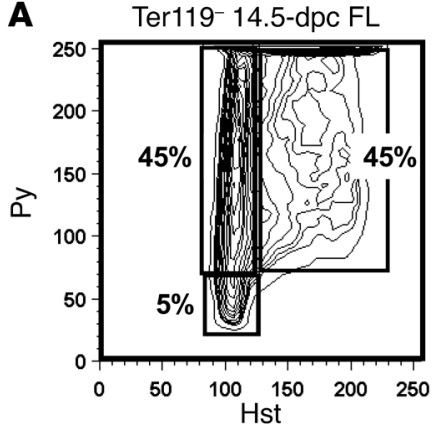

B

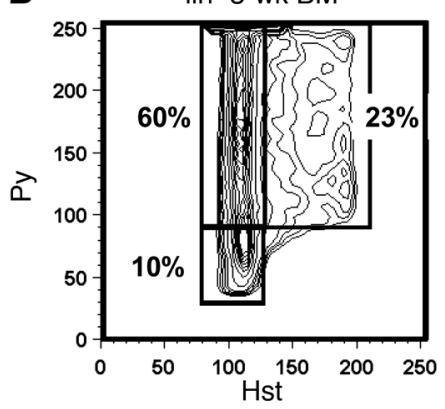

in- 3-wk BM

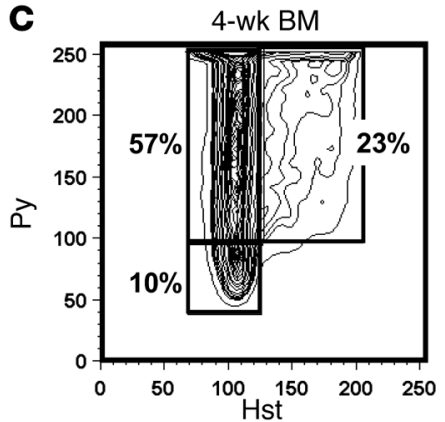

Ter119- 14.5-dpc FL

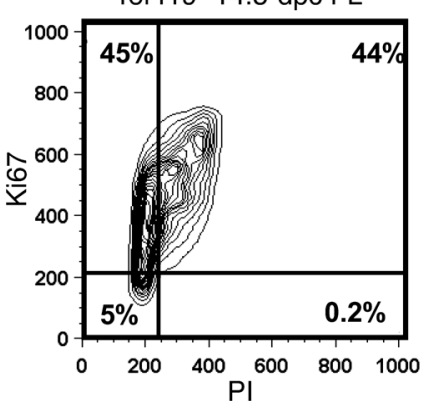

$G_{0}$

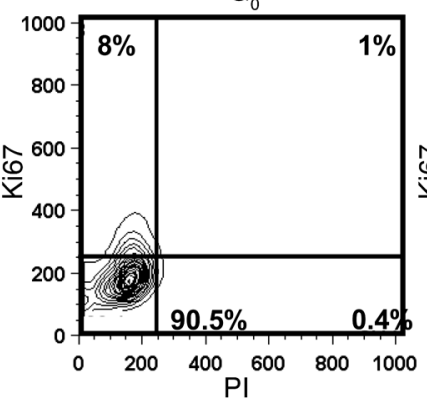

lin- 10-wk BM

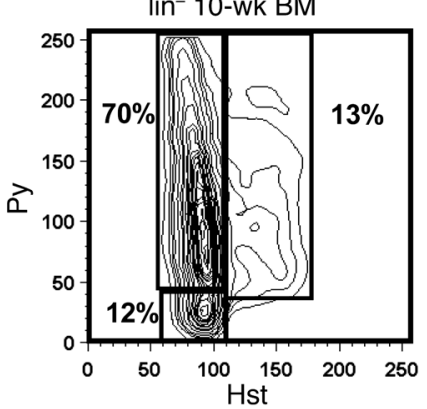

$\mathrm{G}_{1} / \mathrm{S} / \mathrm{G}_{2} / \mathrm{M}$

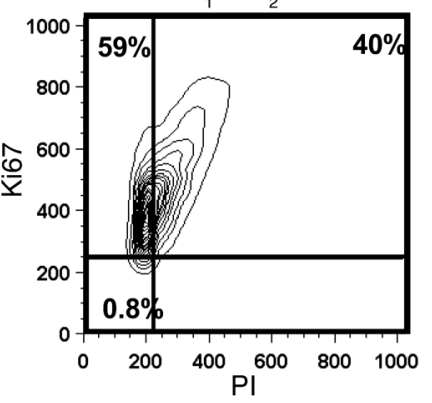

Figure 2

FACS profiles of the distribution of $\mathrm{G}_{0}, \mathrm{G}_{1}$, and $\mathrm{S} / \mathrm{G}_{2} / \mathrm{M}$ cells in different lin- populations. (A) Representative FACS contour plot for 14.5dpc Ter119- FL cells after staining with Hst and Py and for Ki67. (B) Representative FACS contour plot for lin- 3-wk BM cells after staining with Hst and Py; sorted $\mathrm{G}_{0}$ cells after staining for Ki67 (>90\% of the $\mathrm{G}_{0}$ cells showed no Ki67 expression); and sorted $\mathrm{G}_{1} / \mathrm{S} / \mathrm{G}_{2} / \mathrm{M}$ cells after staining for Ki67 (>99\% of the $\mathrm{G}_{1} / \mathrm{S} / \mathrm{G}_{2} / \mathrm{M}$ cells expressed Ki67). (C) Representative FACS contour plots for lin- 4- and 10-wk BM cells after staining with Hst and Py. Percentages indicate the proportion of total cells found within the indicated gene. in the BM of mice at $18.5 \mathrm{dpc}$. For comparison, we also evaluated the cycling status of CRUs in the 18.5-dpc FL. The frequency of CRUs in these 2 tissues was 1 per $10^{5}$ and 1 per $7 \times 10^{4}$ total nucleated cells (Supplemental Table 1; supplemental material available online with this article; doi:10.1172/JCI28310DS1); i.e., approximately 5 - and 3.5 -fold lower, respectively, than in adult BM (1 per $2 \times 10^{4}$ total nucleated cells; ref. 33 ) and 6- and 4-fold lower, respectively, than in the 14.5 -dpc FL $\left(1\right.$ per $1.7 \times 10^{4}$ total nucleated cells; ref. 33). After overnight exposure to high-specific activity ${ }^{3} \mathrm{H}-\mathrm{Tdr}$, no CRUs were detected in the suspensions of either the 18.5-dpc fetal BM cells or the 18.5-dpc FL cells, in contrast to the control cells incubated in the same medium without ${ }^{3} \mathrm{H}-\mathrm{Tdr}$ (Figure 1B). Thus all HSCs in the fetus, regardless of their location, appear to be rapidly proliferating.

To further investigate the pace and timing of the transition of HSCs into a largely quiescent population, we analyzed the cycling status of CRUs in lin- BM cell suspensions from 3- and 4-week-old (weanling) mice (lin- 3- and 4-wk BM, respectively). In initial experiments, the CRU frequencies in the lin $^{-} 3$ - and 4-wk BM cells were found to be the same ( 1 per $6.5 \times 10^{3}$ and 1 per $6.3 \times 10^{3}$ lin $^{-}$cells, respectively; Supplemental Table 2 ), approximately 2 -fold lower than in the lin 10 -wk BM cells (young adult mice; 1 per $2.9 \times 10^{3}$ lin ${ }^{-}$cells). We then fractionated 3- and 4-wk BM cells by FACS into their component $\mathrm{G}_{0}$ and $\mathrm{G}_{1} / \mathrm{S} / \mathrm{G}_{2} / \mathrm{M}$ subsets based on the gates shown in the left panels of Figure 2, B and C, and the sorted $G_{0}$ and $\mathrm{G}_{1} / \mathrm{S} / \mathrm{G}_{2} / \mathrm{M}$ cells were assayed separately for CRU activity. Reanalysis of the sorted $G_{0}$ and $G_{1} / S / G_{2} / M$ fractions after staining for Ki67 confirmed that the cells expressing this proliferation marker were confined to those we had designated as $\mathrm{G}_{1} / \mathrm{S} / \mathrm{G}_{2} / \mathrm{M}$ (Figure $2 \mathrm{~B}$ ). Remarkably, the results of the in vivo assays showed that all of the CRUs detected in the 3-wk BM were also confined to the $\mathrm{G}_{1} / \mathrm{S} / \mathrm{G}_{2} / \mathrm{M}$ fraction, whereas more than $98 \%$ of the CRUs in the 4-wk BM were found in the $\mathrm{G}_{0}$ fraction (Figure 3). Thus, there was a rapid downregulation of CRU proliferative activity in the BM of mice between 3 and 4 weeks of age with little change in CRU number.

$H S C$ in $S / G_{2} / M$ show a specific and reversible engraftment defect regardless of their developmental origin or route of injection into assay recipients. Given the previously reported engraftment defect of adult HSCs stimulated to enter $S / G_{2} / M(19)$, it was of interest to determine whether the number of proliferating HSCs present early in development might be routinely underestimated due an inability to detect those in $S / G_{2} / M$. To investigate this possibility, the $G_{1} / S / G_{2} / M$ population of Ter119- 14.5 -dpc FL cells was subdivided into its component $G_{1}$ and $S / G_{2} / M$ fractions, and each of these 2 subsets was assayed separately for CRUs. In this case, the gate settings chosen to separate the $\mathrm{G}_{1}(2 \mathrm{n}$ DNA) and S-phase cells ( $>2 n$ DNA) were validated by the profiles obtained when the sorted cells were stained with propidium iodide (PI) and reanalyzed by FACS (Figure 4A). 


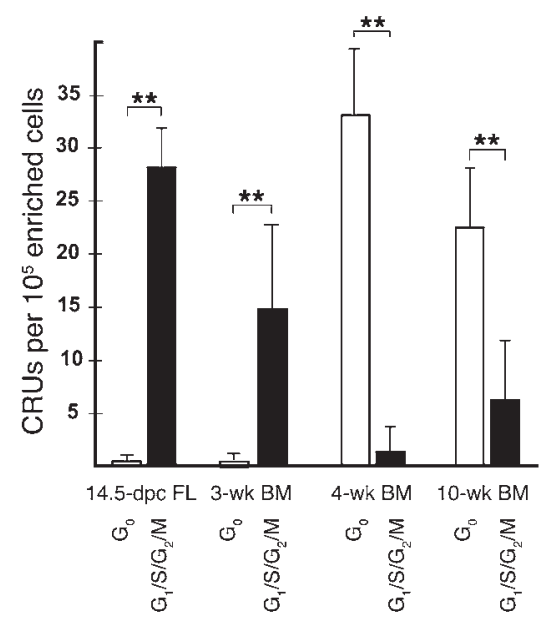

All CRU activity detectable in the $\mathrm{G}_{1} / \mathrm{S} / \mathrm{G}_{2} / \mathrm{M}$ fraction of Ter11914.5-dpc FL cells was confined to the $G_{1}$ subset (Figure $4 B$ and Figure 5A). Similar experiments performed with lin $^{-} 3$-wk BM cells showed that the CRUs in the $\mathrm{G}_{1} / \mathrm{S} / \mathrm{G}_{2} / \mathrm{M}$ population from this source were likewise confined to the $\mathrm{G}_{1}$ fraction (Figure $5 \mathrm{~A}$ and data not shown). It is of interest to note that the $S / G_{2} / M$ defect was specific to repopulating cells able to produce progeny in all lineages for at least 16 weeks. In contrast, cells with short-term repopulating activity ( 8 weeks) were readily detected in the $S / G_{2} / M$ fraction as well as in the $G_{1}$ fraction, thus confirming the restriction of this cell cycle-dependent engrafting defect to cells with sustained multilineage repopulating activity $(34,35)$.

To determine whether the apparent engraftment defect of proliferating CRUs was reversible, we first assayed the CRU content of aliquots of the same isolated $G_{1}$ and $S / G_{2} / M$ cells after they had been incubated for 6 hours at $37^{\circ} \mathrm{C}$ in serum-free medium containing $50 \mathrm{ng} / \mathrm{ml} \mathrm{SF}$. During this time, many of the $\mathrm{G}_{1}$ cells progressed into $S / G_{2} / M$ and many of the $S / G_{2} / M$ cells moved into $G_{1}$, as seen by their altered PI (Figure 4A) and Hst (data not shown) staining profiles. In vivo assays showed that CRU activity reappeared when the $S / G_{2} / M$ cells were cultured for 6 hours, whereas the CRU activity originally present in the $G_{1}$ cells was partially lost (Figure 4B).

\section{Figure 4}

Hst/Py-sorted HSCs display an absolute but transient $S / \mathrm{G}_{2} / \mathrm{M}$ engraftment defect. (A) Ter119- 14.5-dpc FL cells in $G_{1} / S / G_{2} / M$ were fractionated into their component $G_{1}$ and $S / G_{2} / M$ subsets, leaving a slight separation between them. Aliquots of the sorted subsets were then stained with $\mathrm{PI}$ as well as with Hst/Py (data not shown). The sorted cells were cultured for 6 hours and then stained again with PI. We found that during this 6-hour culture period, approximately one-third of the cells originally in $G_{1}$ had progressed into $S / G_{2} / M$, and a similar proportion of the cells originally in $S / G_{2} / M$ had progressed into $G_{1}$. (B) CRUs per $10^{5}$ initial Ter119- FL cells for $G_{1}$ and $S / G_{2} / M$ fractions before and after 6 hours in culture. There was a 3.5-fold loss of CRUs when $G_{1}$ cells were cultured for 6 hours, but no loss when the cultured cells were re-sorted for $\mathrm{G}_{1}$ cells $(P=0.36)$. Conversely, we detected a greater than 65 -fold increase in the number of CRUs detected when $\mathrm{CRUs}$ in $\mathrm{S} / \mathrm{G}_{2} / \mathrm{M}$ were cultured and a greater than 128 -fold increase when the cultured cells were sorted for $\mathrm{G}_{1}$ cells. IF, intrafemoral. Values are mean \pm SEM of results from at least 3 experiments. ${ }^{*} P<0.01$, ${ }^{\star *} P<0.001$ versus respective cell types before culture.

\section{Figure 3}

The cycling activity of CRUs is downregulated between 3 and 4 weeks of age. Shown are the number of CRUs per $10^{5}$ initial total viable cells. FL cells were depleted of Ter119+ cells; for the 3- and 4-wk BM cells, all lin+ cells except Mac1+ cells were removed; and for the 10-wk BM cells, all lin+ cells including Mac1+ cells were removed. Values are mean \pm SEM from data pooled from at least 3 experiments per tissue. ${ }^{\star \star} P<0.001$.

We next asked whether the inability of intravenously transplanted CRUs in $S / G_{2} / M$ to engraft recipient mice might be overcome by injecting the cells directly into the femoral BM space. However, we did not detect any CRUs after intrafemoral injection in this subset of Ter119- 14.5-dpc FL cells (Figure 4B), even though the CRU numbers measured in the corresponding $\mathrm{G}_{1}$ 14.5-dpc FL cells after intrafemoral injection were the same as after intravenous transplantation ( 1 per $3.6 \times 10^{3}$ and 1 per $3.8 \times 10^{3}$ cells, respectively).

The $S / G_{2} / M$ engraftment defect of HSCs is overcome by pretreatment of the host with a CXCL12 antagonist. Previous reports have shown that CXCL12 can promote both the mobilization (36) and the homing (37-39) of HSCs. However, the mobilization of primitive hematopoietic cells can also be stimulated by blocking CXCL12/CXCR4 signaling, as achieved by in vivo administration of AMD3100, a CXCL12 antagonist (40). In addition, it has recently been shown that in vivo administration of AMD3100 can increase the competitive engrafting ability of transplanted $\mathrm{BM}$ cells in unirradiated hosts (41). These findings suggested that targeting the CXCL12/CXCR4 pathway might also affect the variable engraftment properties of cycling HSCs by influencing either the HSCs themselves or the transplanted host. To

A Before culture $\quad \mathrm{G}_{1}+6 \mathrm{~h} \quad \mathrm{~S} / \mathrm{G}_{2} / \mathrm{M}+6 \mathrm{~h}$

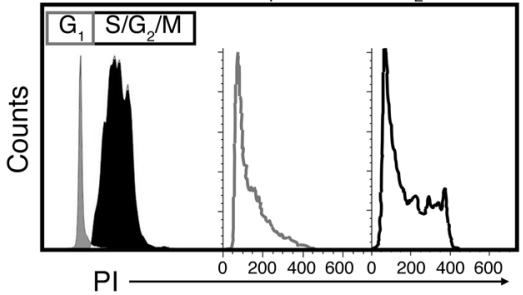

B

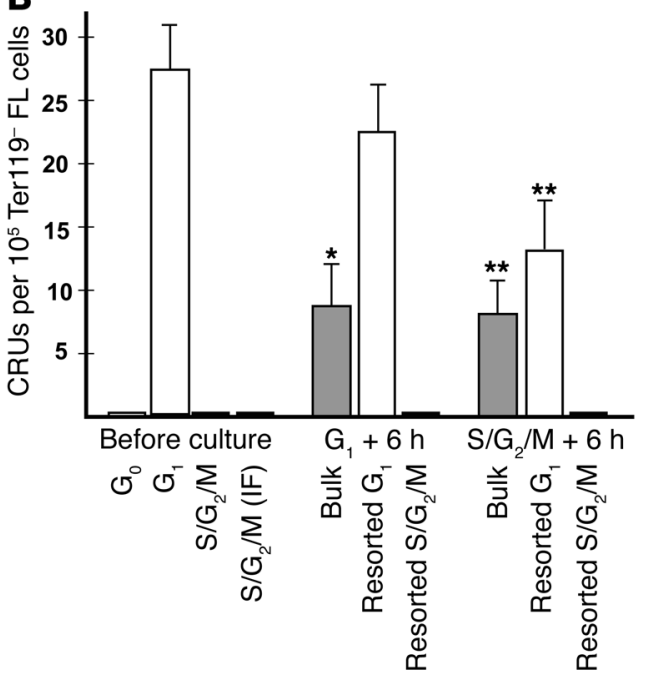


A
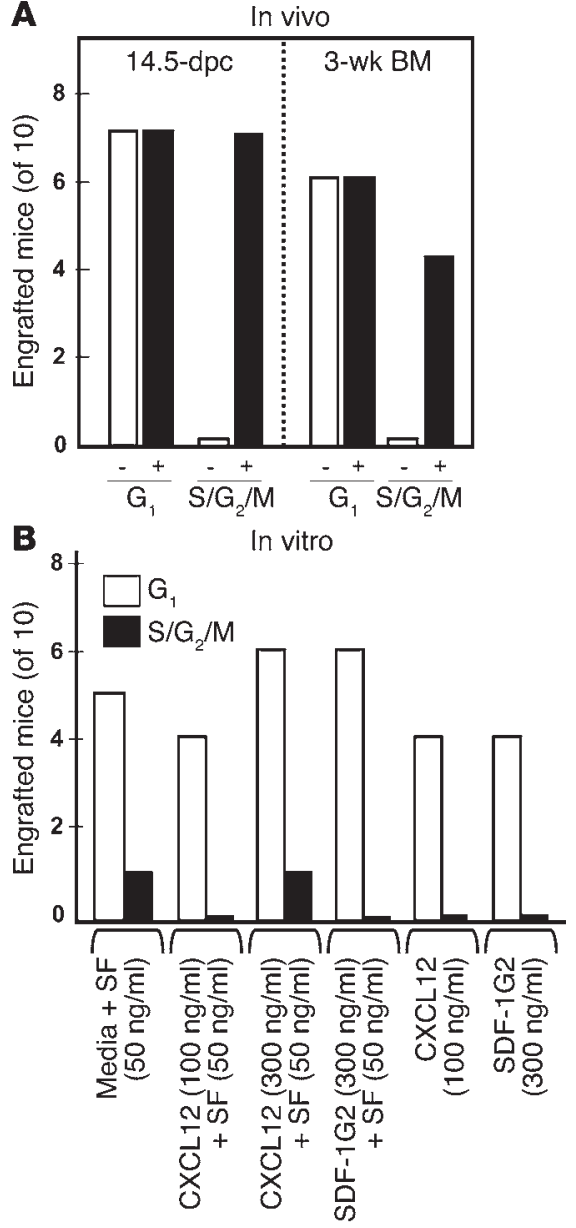

investigate these possibilities, we first asked whether pretreating either the cycling HSCs to be transplanted or their hosts with a specific antagonist of CXCL12 might alter the level of repopulation obtained 16 weeks later. The CXCL12 antagonist used in these experiments was SDF-1G2 (also called P2G because it is identical to stromal cell-derived factor 1 except that the proline at position 2 has been converted to glycine; ref. 42). SDF-1G2 is thus structurally quite different from AMD3100 but similar in its ability to block CXCL12 from binding to CXCR4 without activating CXCR4 $(42,43)$. SDF-1G2 and AMD3100 also share an ability to elicit effects on primitive hematopoietic cells both in vitro and in vivo (44). Mice were injected with $10 \mu \mathrm{g}$ of SDF-1G2 or PBS 2 hours prior to the transplantation of FACS-sorted $G_{1}$ or $S / G_{2} / M$ cells and analyzed for the presence of donor-derived blood cells 16 weeks later, and the results for 14.5-dpc FL and 3-wk BM cells were similar (Figure 5A). Treatment of recipients with SDF-1G2 had no effect on the repopulating activity of CRUs in $\mathrm{G}_{1}$. In contrast, SDF-1G2 pretreatment of recipients of S/G $/ \mathrm{M}$ cells enabled long-term multilineage repopulation to be readily detected (in 7 and 4 mice of 10 transplanted with 14.5 -dpc FL and 3-wk BM $\mathrm{S} / \mathrm{G}_{2} / \mathrm{M}$ cells, respectively, versus 0 of 10 in PBS-injected controls for each). Moreover, the SDF-1G2-pretreated hosts showed levels of repopulation by both sources of $S / \mathrm{G}_{2} / \mathrm{M}$ cells that were indistinguishable from those seen in mice transplanted with $G_{1}$ cells (Figure 6). On the other hand, when SDF-1G2 was applied directly to the cells to be transplanted for 30 minutes before injection,

\section{Figure 5}

The engraftment defect of HSCs in $\mathrm{S} / \mathrm{G}_{2} / \mathrm{M}$ is corrected by treatment of the host, but not the cells, with SDF-1G2. (A) Effect of injecting prospective recipients 2 hours after irradiation and 2 hours prior to transplant with $10 \mathrm{ng} / \mathrm{ml} \mathrm{SDF-1G2} \mathrm{(+)} \mathrm{or} \mathrm{PBS} \mathrm{(-).} \mathrm{Starting} \mathrm{equivalents} \mathrm{of} 4,000 \mathrm{G}_{1}$ cells per recipient mouse or $12,000 \mathrm{~S} / \mathrm{G}_{2} / \mathrm{M}$ cells per recipient mouse were similarly tested. Both 14.5-dpc FL and 3-wk BM HSCs in $S / G_{2} / M$ engrafted only when transplanted into SDF-1G2-treated recipients, whereas treated recipients were no more likely to be engrafted long-term by $\mathrm{HSCs}_{\text {in }} \mathrm{G}_{1}$ than were untreated recipients. Results are combined from 3 independent experiments. (B) Effect of in vitro treatment of sorted Ter119- $F L$ cells in $\mathrm{G}_{1}$ or $\mathrm{S} / \mathrm{G}_{2} / \mathrm{M}$ for 30 minutes at $37^{\circ} \mathrm{C}$ in serum-free medium plus the indicated additives on $\mathrm{CRU}$ detection. In vitro treatment had no significant effect on the number of mice that subsequently showed multilineage repopulation from starting cells in either $G_{1}$ or $S / G_{2} / M$. Results are combined from 3 independent experiments.

no difference in the engrafting activity of the transplanted $G_{1}$ or $\mathrm{S} / \mathrm{G}_{2} / \mathrm{M}$ cells was seen compared with untreated controls over a wide range of SDF-1G2 and CXCL12 concentrations tested, either with or without added SF (Figure 5B).

HSCs in $S / G_{2} / M$ express higher levels of CXCL12 transcripts than do HSCs in $G_{1}$. To begin to understand the mechanism behind the observed HSC S/G $/ \mathrm{G}_{2} / \mathrm{M}$ engraftment defect and how it might be overcome by SDF-1G2 pretreatment of the host, we isolated highly purified populations of HSCs from 14.5-dpc FLs and from 3-wk $\mathrm{BM}\left(\mathrm{lin}^{-} \mathrm{Sca}-1^{+} \mathrm{CD} 43^{+} \mathrm{Mac}^{+}\right.$cells representing approximately $20 \%$ pure HSCs; M.B. Bowie and C.J. Eaves, unpublished observations) and sorted these into their corresponding $G_{0} / G_{1}$ and $S / G_{2} / M$ fractions by Hst staining. Aliquots of approximately $200-800$ cells were collected from each fraction in 3 independent sorting experiments, and transcript levels for Gapdh, c-Kit, c-mpl, CD44, $\alpha 4$-integrin ( $\alpha 4 i n t)$, VCAM1, CXCR4, and CXCL12 were measured by quantitative realtime analysis of the cDNAs prepared from the isolated RNA extracts as described in Methods. Transcripts for all these genes were consistently detected in both the $G_{0} / G_{1}$ and $S / G_{2} / M$ fractions of the highly purified suspensions of HSCs from 14.5-dpc FL and 3-wk BM, including CXCL12, which had not previously been shown to be expressed by HSCs (Figure 7). Interestingly, CXCL12 was also the only one of the genes assessed that was found to be expressed at significantly different levels in $G_{0} / G_{1}$ and $S / G_{2} / M$ HSCs (9-fold higher in $\mathrm{S} / \mathrm{G}_{2} / \mathrm{M}$ HSCs; $P<0.05$ ).

\section{Discussion}

This study presents 2 clinically relevant features of HSC regulation. The first is the unanticipated sudden and complete change in HSC proliferative activity that occurred in juvenile mice between 3 and 4 weeks of age. Both the abruptness and the reproducibility of this change suggest an underlying mechanism that is tightly controlled and broadly active. It is notable that this change was not linked to the migration of HSCs during late embryogenesis from the microenvironment of the FL to that of the BM, but rather was strictly associated with the developmental status of the donor. Thus, although differences between BM and FL niches and stromal cells have been sought and described (45-48), these differences do not appear to directly determine the cycling activity of the HSCs they are thought to regulate. The present data are more consistent with a model in which the mechanism of HSC cycling control in vivo is indirectly controlled by external cues, perhaps via changing stimulation of the stromal cells that then alter the signals they deliver, as suggested by studies of the long-term BM culture system 
A

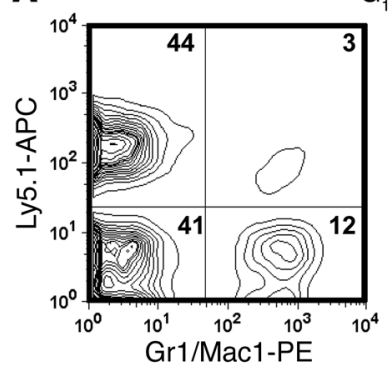

$\mathrm{G}_{1}$ cells into $\mathrm{PBS}$-treated recipient

B

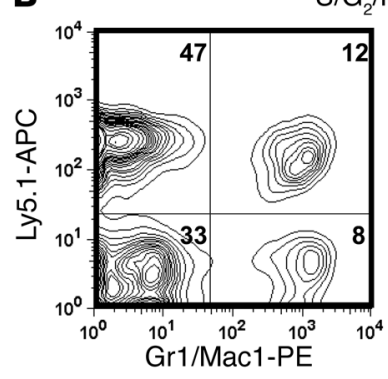

$\mathrm{S} / \mathrm{G}_{2}$
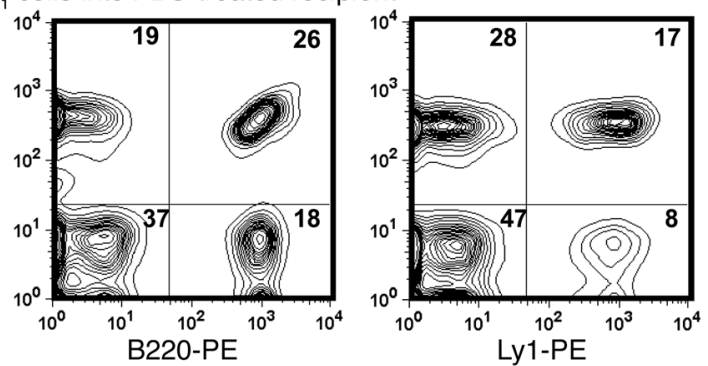

$B 220-P E$

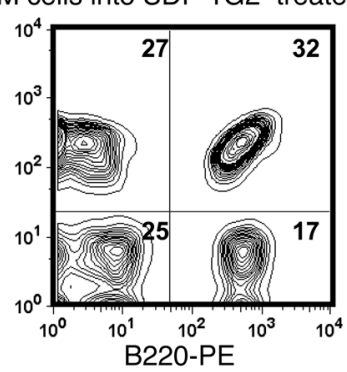

$\mathrm{S} / \mathrm{G}_{2} / \mathrm{M}$ cells into PBS-treated recipient
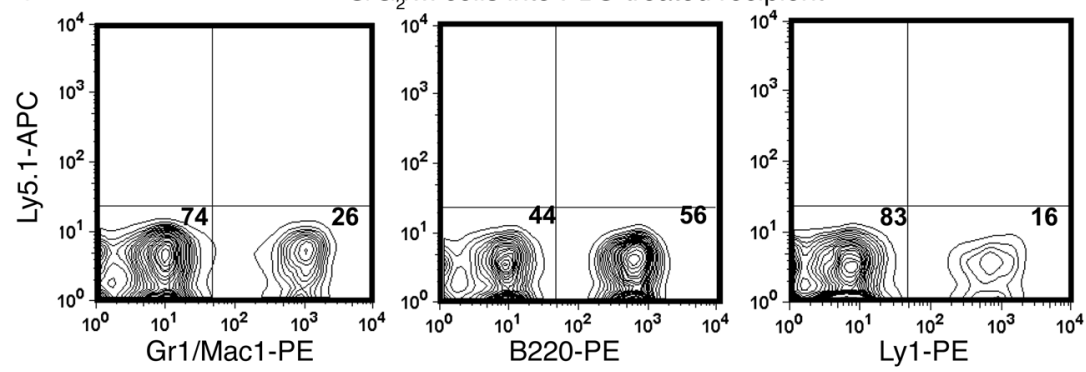

Figure 6

Donor-derived repopulation of SDF-1G2-treated mice. Shown are representative FACS profiles of donor-specific cells detected after dual staining for the donor-type Ly5 allotype and various lineage-specific markers. (A) Example of a positively engrafted PBS-treated recipient of FL cells in $G_{1}$. (B) Example of a positively engrafted SDF-1G2-treated recipient of $F L$ cells in $S / G_{2} / M$. (C) Example of a PBS-treated recipient of $F L$ cells in $S / G_{2} / M$ that did not show donor-derived hematopoiesis. Numbers within graphs indicate the proportion of total cells found within the indicated gene.

$(44,49)$ and of elements of the BM microenvironment in vivo $(25)$. However, internally programmed changes in HSC responsiveness to external factors could also contribute to a developmentally controlled alteration in HSC cycling activity.

In humans, an abrupt change in HSC proliferative activity at an analogous point in development ( $2-4$ years) has been inferred from measurements of the rate of decline in telomere length of circulating leukocytes (50). This suggests that the mechanisms involved in regulating HSC proliferative activity during ontogeny may be preserved across these species and that the mouse will be a relevant model for their future elucidation. It is interesting to note that, in the mouse, a number of other changes in hematopoietic cell properties or output parameters have already been found to change during ontogeny in concert with this transition of the HSC compartment from a predominantly cycling to a predominantly quiescent population. These changes include the initial acquisition of an SP and Rhodull phenotype by HSCs (15) and the completion of appearance and rapid cycling of adult-type $\left(\mathrm{Ly} 49^{+}\right)$natural killer cells and peripheral T cells $(51,52)$.
Many other differences in the properties of fetal and adult HSCs and the programs they dictate have also been described $(13,53,54)$. It will clearly be of interest to determine the extent to which these may be programmatically linked to the mechanisms that precipitate the change in HSC cycling that occurred in mice between 3 and 4 weeks of age. Several genes have been implicated in the differential control of HSC behavior at different stages of development. These include genes encoding various transcription factors, i.e., Runx1 (55), Notch (56), Scl (57), bmi1 (58, 59), and $G f i-1(60,61)$, as well as the growth factor receptors $c$-Kit $(62,63)$ and Tie2 (64). Further delineation of the molecular basis of the unique programs operative in fetal HSCs and how these regulate fetal HSC cycling are of major interest, as this information could lead to new strategies for expanding HSCs and offer potential insights into mechanisms of leukemogenesis.

The second significant set of findings from our studies indicates the universality and pronounced extent of the engraftment defect found to characterize cycling HSCs in the $S / G_{2} / M$ phases of the cell cycle, the specificity of this effect for hematopoietic cells with prolonged versus short-term repopulating activity, and the reversibility of this defect seen either following their progression into $G_{1}$ or when the host was pretreated with a specific antagonist of CXCL12. Interestingly, the corrective effect of in vivo-administered SDF-1G2 could not be replicated by treatment of the cells with this agent prior to injection. The in vivo effect of SDF-1G2 could also not be mimicked by intrafemoral injection of the test cells. The inability of intrafemoral injection to overcome the defective engraftment of HSCs in $S / G_{2} / M$ suggests that this defect is likely mediated by events that affect the transplanted HSCs after they have entered the BM environment.

Quantitative analysis of the level of expression of 7 genes in the $\mathrm{G}_{1}$ and $\mathrm{S} / \mathrm{G}_{2} / \mathrm{M}$ subsets of purified cycling HSCs from both FL and 3-wk BM sources confirmed the expected expression of $c$-Kit, c-mpl, CD44, a4int, VCAM1, and CXCR4 and further revealed that these cells also all contained CXCL12 transcripts. Moreover, although the transcript levels were not different between the $\mathrm{G}_{1}$ and $\mathrm{S} / \mathrm{G}_{2} / \mathrm{M}$ fractions for $c$-Kit, c-mpl, CD44, $\alpha 4 i n t, V C A M 1$, or CXCR4, a 9-fold increase in CXCL12 expression was noted in the $S / G_{2} / M$ HSCs. Previous work has suggested that the ability of transplanted HSCs to reach a niche within the BM that can support their self maintenance may depend on the strength of the CXCL12 gradient they encounter within the BM space, causing them to migrate toward the osteoblasts that line the bone (22). According to such a model, the ability of HSCs to express CXCL12 themselves, in the absence of changes in their expression of CXCR4, might be anticipated to regulate their ability to respond to other more distal sources of CXCL12. Upregulated expression of CXCL12 during the progression of HSCs through $\mathrm{S} / \mathrm{G}_{2} / \mathrm{M}$, as demonstrated here, might then be sufficient to interfere with an appropriate intra-BM migratory 


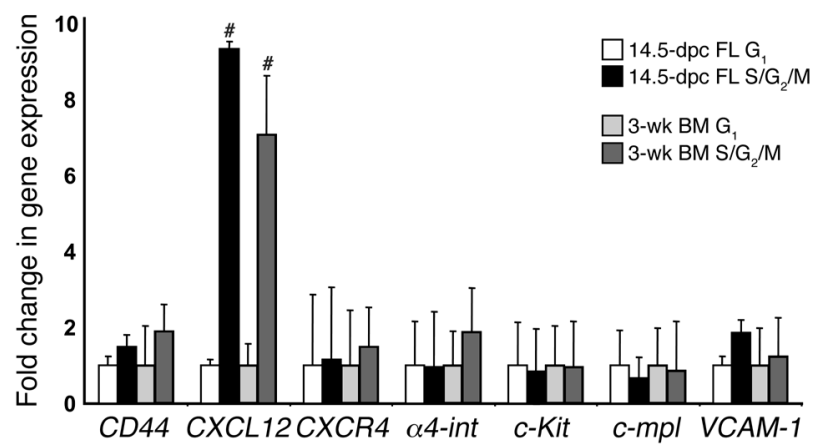

Figure 7

Gene expression analysis of the $G_{1}$ and $S / G_{2} / M$ subsets of highly purified lin-Sca1 ${ }^{+}$CD43+Mac1+ HSCs from 14.5-dpc FL and 3-wk BM. Gene expression in $G_{1}$ was set as 1 , and the fold change in transcript levels in the corresponding $S / G_{2} / M$ fraction is shown. Results are mean \pm SEM of data from 2-3 biological replicates measured in triplicate. $\# P<0.05$ versus respective $\mathrm{G}_{1}$ samples.

response, resulting in the rapid differentiation, death, or irreversible sequestration of these cells in a site where they could not be stimulated to divide. Timed blockade of CXCR4 on cells within the BM by injected SDF-1G2 might then increase the level of intra-BM CXCL12 to a point that transiently restores an effective chemoattractant gradient for the otherwise-insensitive HSCs in $\mathrm{S} / \mathrm{G}_{2} / \mathrm{M}$. Such a possibility has, in fact, recently been modeled in the zebrafish, where overexpression of CXCL12 in the germ cells was found to prevent the normal migration of these cells toward endogenous CXCL12 signals (65).

In the hematopoietic system, it is interesting to note that long-term repopulating CXCL12-/- HSCs engrafted irradiated hosts, whereas only short-term repopulation was obtained from CXCR4 $4^{-/-}$cells (66, 67). In addition, as would be predicted from the explanation we have advanced, forced overexpression of CXCR4 in retrovirally transduced (i.e., proliferating) human HSCs was able to enhance the in vivo engrafting activity of these cells (68), and, conversely, treatment with antibodies to CXCR4 had the opposite effect (69). However, CXCL12 levels in the BM are also subject to regulation, as occurs, for example, following the administration of G-CSF (70).

Recently, Chen et al. (41) found that administration of AMD3100 pretransplant can produce a modest improvement in the engraftment of quiescent adult BM HSCs transplanted into nonirradiated hosts. The mechanism proposed was that the injected AMD3100 initiated the mobilization of endogenous HSCs within the BM, thereby improving the ability of the incoming transplanted HSCs to compete for niche occupancy. The studies of Chen et al. thus differed in several respects from those described here, where the effects on engraftment were assessed in sublethally irradiated hosts and found to be exclusive for transplanted HSCs in $\mathrm{S} / \mathrm{G}_{2} / \mathrm{M}$ at the time of injection. Therefore, it seems unlikely that the mechanisms responsible for the enhanced engraftment seen in both experimental models are identical, in spite of the fact that they are both initiated by treatment of the host with a CXCL12 antagonist.

The fact that proliferating human HSCs show the same engraftment defect when they transit $S / G_{2} / M$ is noteworthy (20) and underscores the clinical implications of these findings. For example, our results predict that intrafemoral injection of transplants is unlikely to be a useful strategy for improving the therapeutic effectiveness of HSCs induced to expand in vitro. To date, interference of CXCL12 action by specific CXCR4 inhibitors has been used primarily for enhancing the yield of HSCs from donors for transplantation into myeloablated patients $(71,72)$. Another application of such inhibitors suggested by the findings reported here could be to treat recipients of cycling cell transplants. Thus significant benefit might also be derived by pretreatment of the host, particularly when transplants of genetically modified or cultured cells are to be administered, since half of the HSCs in an asynchronously dividing population would be expected to be in $S / G_{2} / M$.

\section{Methods}

Mice. Ly5-congenic strains of C57BL/6 mice were used as donors and recipients. All recipients were also homozygous for the $W^{41}$ allele. Mice were bred and maintained in microisolators with sterile food, water, and bedding at the BC Cancer Research Centre. All experimental protocols were approved by the University of British Columbia Animal Care Committee.

Cells. Single-cell suspensions were prepared in Hank's balanced salt solution containing $2 \%$ FCS (HF/2; StemCell Technologies). Enriched populations of HSCs were obtained by immunomagnetic removal of Ter $119^{+}$or $\operatorname{lin}^{+}$cells from FL and BM cell suspensions, respectively (using EasySep; StemCell Technologies). Antibodies used for isolation of lin $^{-}$cells between 4 and 10 weeks of age were anti-B220, Ter119, anti-Gr1, anti-Ly1, and antiMac1 (StemCell Technologies). To isolate lin ${ }^{-}$cells from 3-week-old mice, the Mac1 antibody was omitted because Mac1 is known to be expressed on fetal and cycling HSCs $(13,14,73)$.

Tritiated ${ }^{3} \mathrm{H}$-Tdr suicide assay. Cells were suspended at $10^{6} / \mathrm{ml}$ in Iscove's medium containing $5 \times 10^{-5} \mathrm{~mol} / 12$-mercaptoethanol, a serum substitute (BIT 9500; StemCell Technologies), and $50 \mathrm{ng} / \mathrm{ml}$ murine SF (StemCell Technologies). Equal volumes were then incubated at $37^{\circ} \mathrm{C}$ in $5 \% \mathrm{CO}_{2}$ in air for 16 hours in $35-\mathrm{mm}$ petri dishes in the presence or absence of $20 \mu \mathrm{Ci} / \mathrm{ml}{ }^{3} \mathrm{H}$ $\operatorname{Tdr}(25 \mathrm{Ci} / \mathrm{mmol}$; Amersham Biosciences). The cells were then harvested and washed twice with Iscove's medium containing $2 \%$ FCS, and limiting dilution CRU assays were performed.

FACS isolation and analysis of cells in different cell cycle phases. Cells were suspended in $\mathrm{HF} / 2$ containing $1 \mu \mathrm{g} / \mathrm{ml} \mathrm{Hst} \mathrm{(Invitrogen)} \mathrm{and} \mathrm{either} 10 \mu \mathrm{mol} / \mathrm{l}$ fumitremorgin C (a gift from S. Bates, NIH, Bethesda, Maryland, USA) or $50 \mu \mathrm{mol} / 1$ reserpine (Sigma-Aldrich) and then incubated at $37^{\circ} \mathrm{C}$ for 45 minutes. Py (Sigma-Aldrich) was added at $1 \mu \mathrm{g} / \mathrm{ml}$, and the cells were incubated for another 45 minutes at $37^{\circ} \mathrm{C}$. Cells were washed twice in $\mathrm{HF} / 2$ with $1 \mu \mathrm{g} / \mathrm{ml} \mathrm{PI}$ (Sigma-Aldrich) in the second wash and were finally resuspended in HF/2 with PI and kept on ice in the dark until being sorted (PIcells only) on a 3-laser FACSVantage (BD). For analysis of DNA content, cells were either restained with Hst only using the same protocol or stained with PI at least 1 hour after storage at $4{ }^{\circ} \mathrm{C}$ of cells that had been washed twice in ice-cold PBS with $0.1 \%$ glucose and fixed in $1 \mathrm{ml}$ ice-cold $70 \%$ ethanol. To stain with PI, cells were washed twice with $2 \%$ PBS and resuspended in PBS with $0.1 \%$ glucose, $5 \mu \mathrm{g} / \mathrm{ml} \mathrm{PI}$, and $200 \mu \mathrm{g} / \mathrm{ml}$ RNase A. Cells were then incubated for at least 1 hour at $4^{\circ} \mathrm{C}$ and analyzed directly on a FACSCalibur (BD). To stain sorted cells for Ki67, the cells were washed, resuspended in $50 \mu \mathrm{l}$ ice-cold $80 \%$ ethanol, and incubated at $-20^{\circ} \mathrm{C}$ for at least 2 hours. The fixed cells were washed twice in $300 \mu \mathrm{l} \mathrm{PBS}$ with 1\% FCS and $0.09 \% \mathrm{NaN} 3$ (pH 7.2). FITC-conjugated anti-human Ki67 antibody (BD) was then added, and the cells were incubated for 30 minutes at room temperature in the dark. Cells were then analyzed by FACS, with cells stained with a FITC-conjugated mouse $\operatorname{IgG}_{1}(\mathrm{BD})$ serving as a control.

In vitro treatment of $S / G_{2} / M H S C s$. Sorted cells were incubated at $37^{\circ} \mathrm{C}$ in $5 \%$ $\mathrm{CO}_{2}$ in air in the wells of a round-bottom 96-well plate in serum-free media (as in the ${ }^{3} \mathrm{H}-\mathrm{Tdr}$ suicide assays) with 1 of the following 6 additions: $100 \mathrm{ng} / \mathrm{ml}$ CXCL12 (a gift from I. Clark-Lewis, University of British Columbia, Vancouver, British Columbia, Canada) or $300 \mathrm{ng} / \mathrm{ml}$ SDF-1G2 (also a gift from I. 
Clark-Lewis, now available at cost as a requested peptide from the Biomedical Research Centre, University of British Columbia) but no SF; $50 \mathrm{ng} / \mathrm{ml} \mathrm{SF}$ alone; $50 \mathrm{ng} / \mathrm{ml} \mathrm{SF}$ plus $100 \mathrm{ng} / \mathrm{ml} \mathrm{CXCL12} \mathrm{or} 300 \mathrm{ng} / \mathrm{ml} \mathrm{CXCL12;} \mathrm{or} 300 \mathrm{ng} / \mathrm{ml}$ SDF-1G2. Cells were then harvested from the wells, and equal aliquots were injected into recipient mice such that each mouse received the equivalent of either $4 \times 10^{3}$ starting $\mathrm{G}_{1}$ cells or $1.2 \times 10^{4}$ starting $\mathrm{S} / \mathrm{G}_{2} / \mathrm{M}$ cells.

CRU assay. Recipient $\left(W^{41} / W^{41}\right)$ mice were sublethally irradiated with either $400 \mathrm{cGy}{ }^{137} \mathrm{Cs} \gamma$-rays or $360 \mathrm{cGy} 250 \mathrm{kVp}$ X-rays and then injected intravenously with the test cells, except when injected intrafemorally as indicated. Intrafemoral injections were performed as described previously (74). CRUs were identified by their ability to have generated $\geq 1 \%$ donor Ly5-type blood cells including Ly $1^{+}$( $\mathrm{T}$ cell), B220 ${ }^{+}$(B cell), and Gr1/Mac1 ${ }^{+}$ (granulocyte/monocyte) subsets that could be detected 16 weeks or later after transplantation (75). CRU frequencies were calculated using the L-calc program (StemCell Technologies) from the proportions of mice given various doses of test cells that were negative for this endpoint. Recipients treated with SDF-1G2 were injected intravenously with $10 \mu \mathrm{g}$ per mouse of SDF-1G2 dissolved in PBS 2 hours after being irradiated and were then transplanted another 2 hours later. This schedule was used in an attempt to minimize direct interaction of the injected HSCs with SDF-1G2 in the circulation (based on the likely rapid clearance of SDF-1G2) and to maximize any potential effect on the host by keeping the interval between SDF-1G2 injection and the transplant as short as possible. Controls were injected with PBS instead of the SDF-1G2.

Real-time PCR. Cells were sorted into $1 \mathrm{ml} \mathrm{HF} / 10$, and RNA was isolated using the PicoPure RNA Isolation Kit (Arcturus) as recommended by the supplier including a 15-minute DNAse1 treatment (QIAGEN) on the column at room temperature. RNA was eluted into an $11-\mu$ l volume and stored at $-80^{\circ} \mathrm{C}$. A cDNA preparation was then generated using the SuperScript III First-Strand Synthesis System for RT-PCR (18080093; Invitrogen) as recommended by the manufacturer, with the reaction scaled up to use $25 \mu$ l. Quantitative real-time PCR was performed using the following primer pairs $\left(5^{\prime}\right.$ to $\left.3^{\prime}\right)$ : $\alpha 4$ int (NM_010576.2) forward, AGGACACACCAGGCATTCAT; reverse, CCTCAGTGTTTCGTTTGGTG; CD44 (NM_009851.1) forward, CTTTATCCGGAGCACCTTGGCCACC; reverse, GTCACAGTGCGGGAACTCC; c-Kit (NM_021099.2) forward, ACAAGAG-
GAGATCCGCAAGA; reverse, GAAGCTCAGCAAATCATCCAG; $c-m p l$ (NM_010823.1) forward, AGTGGCAGCACCAGTCATCT; reverse, GAGATGGCTCCAGCACCTT; CXCR4 (NM_009911.2) forward, CGGAGTCAGAATCCTCCAGT; reverse, CTGGTCAGTCTCTTATATCTGGAAAA; Gapdh (NM_008084) forward, AACTTTGGCATTGTGGAAGG; reverse, ATGCAGGGATGATGTTCTGG; CXCL12 (NM_001012477) forward, GAGCCAACGTCAAGCATCTG; reverse, CGGGTCAATGCACACTTGTC; VCAM1 (NM_011693.2) forward, TGATTGGGAGAGACAAAGCA; reverse, AACAACCGAATCCCCAACTT. The relative expression changes were determined as previously described (76), and the housekeeping Gapdh gene transcript was used to normalize the results.

Statistics. Comparisons were made using the Wald test. $P$ values of less than 0.05 were considered significant.

\section{Acknowledgments}

We acknowledge expert technical assistance from the Flow Cytometry Facility of the Terry Fox Laboratory and the Animal Resource Centre of the BC Cancer Research Centre. We acknowledge P. Eirew for statistical advice. This work was supported by grants from the National Cancer Institute of Canada (with funds from the Terry Fox Foundation) and the Stem Cell Network and NIH grant P01 HL-55435 from the National Heart, Lung, and Blood Institute. M. Bowie and D. Kent were both recipients of Stem Cell Network Studentships and Studentships funded by the Canadian Institute of Health Research and the Michael Smith Foundation for Health Research. P. Hoodless is a Canadian Institutes of Health Research New Investigator and a Michael Smith Foundation for Health Research Scholar.

Received for publication February 21, 2006, and accepted in revised form July 11, 2006.

Address correspondence to: Connie J. Eaves, Terry Fox Laboratory, 675 West 10th Avenue, Vancouver, British Columbia V5Z 1L3, Canada. Phone: (604) 675-8122; Fax: (604) 877-0712; E-mail: ceaves@bccrc.ca.
1. Szilvassy, S.J., Humphries, R.K., Lansdorp, P.M., Eaves, A.C., and Eaves, C.J. 1990. Quantitative assay for totipotent reconstituting hematopoietic stem cells by a competitive repopulation strategy. Proc. Natl. Acad. Sci. U. S. A. 87:8736-8740.

2. Harrison, D.E., Astle, C.M., and Lerner, C. 1984 Ultimate erythropoietic repopulating abilities of fetal, young adult, and old adult cells compared using repeated irradiation. J. Exp. Med. 160:759-771.

3. Fleming, W.H., et al. 1993. Functional heterogeneity is associated with the cell cycle status of murine hematopoietic stem cells. J. Cell Biol. 122:897-902.

4. Leemhuis, T., et al. 1996. Isolation of primitive human bone marrow hematopoietic progenitor cells using Hoechst 33342 and Rhodamine 123. Exp. Hematol. 24:1215-1224.

5. Osawa, M., Hanada, K., Hamada, H., and Nakauchi, H. 1996. Long-term lymphohematopoietic reconstitution by a single CD34-low/negative hematopoietic stem cell. Science. 273:242-245.

6. Randall, T.D., Lund, F.E., Howard, M.C., and Weissman, I.L. 1996. Expression of murine CD38 defines a population of long-term reconstituting hematopoietic stem cells. Blood. 87:4057-4067.

7. Bertoncello, I., Hodgson, G.S., and Bradley, T.R. 1985. Multiparameter analysis of transplantable hemopoietic stem cells: I. The separation and enrichment of stem cells homing to marrow and spleen on the basis of rhodamine-123 fluorescence. Exp. Hematol. 13:999-1006.
8. Spangrude, G.J., and Johnson, G.R. 1990. Resting and activated subsets of mouse multipotent hematopoietic stem cells. Proc. Natl. Acad. Sci. U. S. A. 87:7433-7437.

9. Wolf, N.S., Kone, A., Priestley, G.V., and Bartelmez, S.H. 1993. In vivo and in vitro characterization of long-term repopulating primitive hematopoietic cells isolated by sequential Hoechst 33342-rhodamine 123 FACS selection. Exp. Hematol. 21:614-622.

10. Scharenberg, C.W., Harkey, M.A., and Torok-Storb, B. 2002. The ABCG2 transporter is an efficient Hoechst 33342 efflux pump and is preferentially expressed by immature human hematopoietic progenitors. Blood. 99:507-512.

11. Tajima, F., Deguchi, T., Laver, J.H., Zeng, H., and Ogawa, M. 2001. Reciprocal expression of CD38 and CD34 by adult murine hematopoietic stem cells. Blood. 97:2618-2624.

12. Tajima, F., Sato, T., Laver, J.H., and Ogawa, M. 2000. CD34 expression by murine hematopoietic stem cells mobilized by granulocyte colony-stimulating factor. Blood. 96:1989-1993.

13. Rebel, V.I., et al. 1996. A comparison of long-term repopulating hematopoietic stem cells in fetal liver and adult bone marrow from the mouse. Exp. Hematol. 24:638-648.

14. Morrison, S.J., Hemmati, H.D., Wandycz, A.M., and Weissman, I.L. 1995. The purification and characterization of fetal liver hematopoietic stem cells. Proc. Natl. Acad. Sci. U. S. A. 92:10302-10306.
15. Uchida, N., et al. 2004. ABC transporter activities of murine hematopoietic stem cells vary according to their developmental and activation status. Blood. 103:4487-4495.

16. Passegue, E., Wagers, A.J., Giuriato, S., Anderson, W.C., and Weissman, I.L. 2005. Global analysis of proliferation and cell cycle gene expression in the regulation of hematopoietic stem and progenitor cell fates. J. Exp. Med. 202:1599-1611.

17. Benveniste, P., Cantin, C., Hyam, D., and Iscove, N.N. 2003. Hematopoietic stem cells engraft in mice with absolute efficiency. Nat. Immunol. 4:708-713.

18. Matsuzaki, Y., Kinjo, K., Mulligan, R.C., and Okano, H. 2004. Unexpectedly efficient homing capacity of purified murine hematopoietic stem cells. Immunity. 20:87-93.

19. Habibian, H.K., et al. 1998. The fluctuating phenotype of the lymphohematopoietic stem cell with cell cycle transit. J. Exp. Med. 188:393-398.

20. Glimm, H., Oh, I.H., and Eaves, C.J. 2000. Human hematopoietic stem cells stimulated to proliferate in vitro lose engraftment potential during their $\mathrm{S} / \mathrm{G}(2) / \mathrm{M}$ transit and do not reenter $\mathrm{G}(0)$. Blood. 96:4185-4193.

21. Orschell-Traycoff, C.M., et al. 2000. Homing and engraftment potential of Sca- $1^{+}$lin ${ }^{-}$cells fractionated on the basis of adhesion molecule expression and position in cell cycle. Blood. 96:1380-1387.

22. Lapidot, T., Dar, A., and Kollet, O. 2005. How do stem cells find their way home? Blood. 106:1901-1910. 
23. Denhardt, D.T., Noda, M., O’Regan, A.W., Pavlin, D., and Berman, J.S. 2001. Osteopontin as a means to cope with environmental insults: regulation of inflammation, tissue remodeling, and cell survival. J. Clin. Invest. 107:1055-1061.

24. Lee, B.C., et al. 2003. P2Y-like receptor, GPR105 (P2Y14), identifies and mediates chemotaxis of bone-marrow hematopoietic stem cells. Genes Dev. 17:1592-1604.

25. Stier, S., et al. 2005. Osteopontin is a hematopoietic stem cell niche component that negatively regulates stem cell pool size. J. Exp. Med. 201:1781-1791.

26. Bonig, H., Priestly, G.V., and Papayannopoulou, T. 2006. Hierarchy of molecular-pathway usage in bone marrow homing and its shift by cytokines. Blood. 107:79-86

27. Becker, P.S., et al. 1999. Adhesion receptor expression by hematopoietic cell lines and murine progenitors: modulation by cytokines and cell cycle status. Exp. Hematol. 27:533-541.

28. Medvinsky, A.L., Samoylina, N.L., Muller, A.M., and Dzierzak, E.A. 1993. An early pre-liver intra-embryonic source of CFU-S in the developing mouse. Nature. 364:64-66

29. Gothert, J.R., et al. 2005. In vivo fate tracing studies using the SCL stem cell enhancer: embryonic hematopoietic stem cells significantly contribute to adult hematopoiesis. Blood. 105:2724-2732.

30. Ponchio, L., Conneally, E., and Eaves, C. 1995. Quantitation of the quiescent fraction of long-term cultureinitiating cells in normal human blood and marrow and the kinetics of their growth factor-stimulated entry into S-phase in vitro. Blood. 86:3314-3321.

31. Uchida, N., Dykstra, B., Lyons, K.J., Leung, F.Y., and Eaves, C.J. 2003. Different in vivo repopulating activities of purified hematopoietic stem cells before and after being stimulated to divide in vitro with the same kinetics. Exp. Hematol. 31:1338-1347.

32. Ladd, A.C., et al. 1997. Orderly process of sequential cytokine stimulation is required for activation and maximal proliferation of primitive human bone marrow $\mathrm{CD} 34+$ hematopoietic progenitor cells residing in G0. Blood. 90:658-668.

33. Szilvassy, S.J., Ragland, P.L., Miller, C.L., and Eaves, C.J. 2003. The marrow homing efficiency of murine hematopoietic stem cells remains constant during ontogeny. Exp. Hematol. 31:331-338.

34. Szilvassy, S.J., Meyerrose, T.E., and Grimes, B. 2000 Effects of cell cycle activation on the short-term engraftment properties of ex vivo expanded murine hematopoietic cells. Blood. 95:2829-2837.

35. Glimm, H., et al. 2001. Previously undetected human hematopoietic cell populations with short-term repopulating activity selectively engraft NOD/SCID- $\beta 2$ microglobulin-null mice. J. Clin Invest. 107:199-206.

36. Hattori, K., et al. 2001. Plasma elevation of stromal cell-derived factor-1 induces mobilization of mature and immature hematopoietic progenitor and stem cells. Blood. 97:3354-3360

37. Cashman, J., Dykstra, B., Clark-Lewis, I., Eaves, A., and Eaves, C. 2002. Changes in the proliferative activity of human hematopoietic stem cells in NOD/SCID mice and enhancement of their transplantability after in vivo treatment with cell cycle inhibitors. J. Exp. Med. 196:1141-1149.

38. Fukuda, S., Broxmeyer, H.E., and Pelus, L.M. 2005. Flt3 ligand and the Flt3 receptor regulate hematopoietic cell migration by modulating the SDF-1alpha(CXCL12)/CXCR4 axis. Blood. 105:3117-3126.
39. Lapidot, T., and Kollet, O. 2002. The essential roles of the chemokine SDF-1 and its receptor CXCR4 in human stem cell homing and repopulation of transplanted immune-deficient NOD/SCID and NOD/ SCID/B2m(null) mice. Lenkemia. 16:1992-2003.

40. De Clercq, E. 2005. Potential clinical applications of the CXCR4 antagonist bicyclam AMD3100. Mini Rev. Med. Chem. 5:805-824.

41. Chen, J., et al. 2006. Mobilization as a preparative regimen for hematopoietic stem cell transplantation. Blood. 107:3764-3771.

42. Crump, M.P., et al. 1997. Solution structure and basis for functional activity of stromal cell-derived factor-1; dissociation of CXCR4 activation from binding and inhibition of HIV-1. EMBO J. 16:6996-7007.

43. De Clercq, E. 2003. The bicyclam AMD3100 story. Nat. Rev. Drug Discov. 2:581-587.

44. Cashman, J., Clark-Lewis, I., Eaves, A., and Eaves, C. 2002. Stromal-derived factor 1 inhibits the cycling of very primitive human hematopoietic cells in vitro and in NOD/SCID mice. Blood. 99:792-799.

45. Moore, K.A. 2004. Recent advances in defining the hematopoietic stem cell niche. Curr. Opin. Hematol. 11:107-111.

46. Heissig, B., et al. 2005. A role for niches in hematopoietic cell development. Hematology. 10:247-253.

47. Lemischka, I.R. 1997. Microenvironmental regulation of hematopoietic stem cells. Stem Cells. 15(Suppl. 1):63-68.

48. Hackney, J.A., et al. 2002. A molecular profile of a hematopoietic stem cell niche. Proc. Natl. Acad. Sci. U. S. A. 99:13061-13066.

49. Eaves, C.J., et al. 1991. Mechanisms that regulate the cell cycle status of very primitive hematopoietic cells in long-term human marrow cultures. II. Analysis of positive and negative regulators produced by stromal cells within the adherent layer. Blood. 78:110-117.

50. Rufer, N., et al. 1999. Telomere fluorescence measurements in granulocytes and T lymphocyte subsets point to a high turnover of hematopoietic stem cells and memory T cells in early childhood. J. Exp. Med. 190:157-167.

51. Dorfman, J.R., and Raulet, D.H. 1998. Acquisition of Ly49 receptor expression by developing natural killer cells. J. Exp. Med. 187:609-618.

52. Jamieson, A.M., Isnard, P., Dorfman, J.R., Coles, M.C., and Raulet, D.H. 2004. Turnover and proliferation of NK cells in steady state and lymphopenic conditions. J. Immunol. 172:864-870.

53. Rebel, V.I., Miller, C.L., Eaves, C.J., and Lansdorp, P.M. 1996. The repopulation potential of fetal liver hematopoietic stem cells in mice exceeds that of their adult bone marrow counterparts. Blood. 87:3500-3507.

54. Pawliuk, R., Eaves, C., and Humphries, R.K. 1996. Evidence of both ontogeny and transplant dose-regulated expansion of hematopoietic stem cells in vivo. Blood. 88:2852-2858.

55. Okuda, T., Nishimura, M., Nakao, M., and Fujita, Y. 2001. RUNX1/AML1: a central player in hematopoiesis. Int. J. Hematol. 74:252-257.

56. Hadland, B.K., et al. 2004. A requirement for Notch1 distinguishes 2 phases of definitive hematopoiesis during development. Blood. 104:3097-3105.

57. Lecuyer, E., and Hoang, T. 2004. SCL: from the origin of hematopoiesis to stem cells and leukemia. Exp. Hematol. 32:11-24.

58. Lessard, J., and Sauvageau, G. 2003. Bmi-1 determines the proliferative capacity of normal and leukaemic stem cells. Nature. 423:255-260.
59. Park,I.K., et al. 2003. Bmi-1 is required for maintenance of adult self-renewing haematopoietic stem cells. Nature. 423:302-305.

60. Hock, H., et al. 2004. Gfi-1 restricts proliferation and preserves functional integrity of haematopoietic stem cells. Nature. 431:1002-1007.

61. Zeng, H., Yucel, R., Kosan, C., Klein-Hitpass, L., and Moroy, T. 2004. Transcription factor Gfi1 regulates self-renewal and engraftment of hematopoietic stem cells. EMBO J. 23:4116-4125.

62. Ikuta, K., and Weissman, I.L. 1992. Evidence that hematopoietic stem cells express mouse c-kit but do not depend on steel factor for their generation. Proc. Natl. Acad. Sci. U. S. A. 89:1502-1506.

63. Miller, C.L., Rebel, V.I., Helgason, C.D., Lansdorp, P.M., and Eaves, C.J. 1997. Impaired steel factor responsiveness differentially affects the detection and long-term maintenance of fetal liver hematopoietic stem cells in vivo. Blood. 89:1214-1223.

64. Puri, M.C., and Bernstein, A. 2003. Requirement for the TIE family of receptor tyrosine kinases in adult but not fetal hematopoiesis. Proc. Natl. Acad. Sci.U.S. A. 100:12753-12758.

65. Doitsidou, M., et al. 2002. Guidance of primordial germ cell migration by the chemokine SDF-1. Cell. 111:647-659.

66. Kawabata, K., et al. 1999. A cell-autonomous requirement for CXCR4 in long-term lymphoid and myeloid reconstitution. Proc. Natl. Acad. Sci. U. S. A. 96:5663-5667.

67. Ma, Q., Jones, D., and Springer, T.A. 1999. The chemokine receptor CXCR4 is required for the retention of B lineage and granulocytic precursors within the bone marrow microenvironment. Immunity. 10:463-471.

68. Brenner, S., et al. 2004. CXCR4-transgene expression significantly improves marrow engraftment of cultured hematopoietic stem cells. Stem Cells. 22:1128-1133.

69. Peled, A., et al. 1999. Dependence of human stem cell engraftment and repopulation of NOD/SCID mice on CXCR4. Science. 283:845-848.

70. Petit, I., et al. 2002. G-CSF induces stem cell mobilization by decreasing bone marrow SDF-1 and upregulating CXCR4. Nat. Immunol. 3:687-694.

71. Broxmeyer, H.E., et al. 2005. Rapid mobilization of murine and human hematopoietic stem and progenitor cells with AMD3100, a CXCR4 antagonist. J. Exp. Med. 201:1307-1318.

72. Flomenberg, N., et al. 2005. The use of AMD3100 plus G-CSF for autologous hematopoietic progenitor cell mobilization is superior to G-CSF alone. Blood. 106:1867-1874.

73. Randall, T.D., and Weissman, I.L. 1997. Phenotypic and functional changes induced at the clonal level in hematopoietic stem cells after 5-fluorouracil treatment. Blood. 89:3596-3606.

74. Mazurier, F., Doedens, M., Gan, O.I., and Dick, J.E. 2003. Rapid myeloerythroid repopulation after intrafemoral transplantation of NOD-SCID mice reveals a new class of human stem cells. Nat. Med. 9:959-963.

75. Szilvassy, S., Nicolini, F.E., Eaves, C.J., and Miller, C.L. 2002. Quantitation of murine and human hematopoietic stem cells by limiting dilution analysis in competitively repopulated hosts. Methods Mol. Med. 63:167-188.

76. Livak, K.J., and Schmittgen, T.D. 2001. Analysis of relative gene expression data using real-time quantitative PCR and the 2(-delta delta $\mathrm{C}(\mathrm{T}))$ method. Methods. 25:402-408. 